\title{
Reviews
}

\section{Politics most unusual: Violence, sovereignty and democracy in the 'war on terror'}

\author{
Damian Cox, Michael Levine and Saul Newman \\ Palgrave Macmillan, Basingstoke, 2009, xiv + 198pp., £55, \\ ISBN: 978-0230535398
}

Contemporary Political Theory (2012) 11, e1-e3. doi:10.1057/cpt.2010.30

In this provocative and stimulating book, the three authors set out an account of what they label 'politics most unusual': a version of politics in the western liberal democratic world that in the aftermath of September 11th, 2001 and the war on terror is decreasingly liberal and democratic to a near-catastrophic extent. The key villains of the piece are familiar: George W. Bush, Tony Blair, neo-conservative politics in the United States, neo-liberal capitalism on a global scale, a co-opted media, supine 'mainstream' intellectuals and a discourse of securitisation that portrays any opposition as 'terrorist'. The victims are also familiar: civil liberties, governmental accountability, vulnerable minorities, the character of 'politics' itself.

As such, 'Politics Most Unusual' could be another among several books offering an account of post-9/11 politics that is broadly 'critical' in tone, deploying the political theory of the post-structural left (governmentality, states of exception and so on) to decry the way in which politics has been all but lost in the face of a wave of authoritarianism, conservatism, commercial interest and elitism that has exploited the potential of the war on terror in a brutal, mendacious, murderous and highly effective fashion. All of these elements are indeed present in Cox, Levine and Newman's work: the political class of the West is reduced to George W. Bush, Tony Blair and indeterminate 'others' (with the occasional honourable mention of Australia's John Howard); the familiar cause célèbres of Abu Ghraib, Guantanamo Bay, Jean Charles de Menezes (to whom the book is dedicated); the USA Patriot Act and UK antiterrorism legislation are also here in strength. As such, at one level, the book offers an account of post-9/11 politics that will be familiar to many and which is likely to spark predictable reactions, depending on your take on this kind of critique.

For some it will be a well-written and accessible account of how it is that the regressive forces of western politics have seized control of almost all aspects of social, political and economic life in the name of 'security' and the protection of the people from a massively distorted and inflated, if not plain invented, 
terrorist 'threat'. The tools of post-structural political theory and a ready willingness to call a lie a lie combine to reveal how the public have been duped, browbeaten and plain coerced into a politics devoid of serious content and in thrall to the manipulation of fear designed to legitimise and augment authority structures running beyond accountability to even epistemological standards of truth, let alone the people they proclaim themselves to serve and protect. At the other end of the spectrum it may seem to some to be a (self-) righteous and clever-clever effort at using abstruse political theory to sustain an account of the hijacking of politics that is as implausible as any other conspiracy theory about the devilishly cunning and massively well-organised forces of a global politico-economic elite that was just waiting for an opportunity like $9 / 11$ to unleash its master plan to take politics away from the people and hand it over to the military-industrial-political complex.

Beyond this, though, and what makes the book more interesting and important, is the benefits that arise from the different perspectives and experiences of the three authors. The chapters that draw on a psychoanalytical approach to consider religion, prejudice, violence and the act of lying, are distinctive and valuable contributions to the political theory of the war on terror that take seriously issues that are often neglected. Also welcome is a strong commitment to the normative dimension of political theory, of which some post-structuralist accounts can be wary for familiar epistemological reasons. The book resonates with anger and an anguished concern for the damage that has been done to liberty, democracy and a properly political account of participation that establishes meaningful and effective mechanisms of accountability. This is not a sterile exercise in analysis or a careful conceptual exposition, and those who like their political theory to be of that ilk will find plenty of room for criticism. Instead, it is a deeply committed political book that uses political theory and philosophy as ways to explore, challenge, critique and berate the politics of the western world of the last decade. The book's final chapter is an appeal for a revival of politics that highlights how political theory at its most engaging and most committed can produce not just powerful analysis but also a call to political arms and action.

There are some absences that typically occur in this sort of work: anger and aguish for the victims of 'western' repression, torture and violence yet comparative near-silence over those imprisoned, tortured and murdered including by public beheading on the web - by people as lying, racist, bigoted and fundamentalist as anyone in the West. This curious moral asymmetry is matched by an asymmetrical account of politics in the West that portrays life pre-9/11 in a fashion verging on the misty-eyed in its assumptions about past respect for secular reason, rights and constitutional order predicated on the rule of law. There is a curious conservatism about the longing for a past that Bush, Blair and company are assumed to have destroyed but which, in reality, 
never really existed. Campaigns like that by the UK government against the IRA may not have had the body-count of the Iraq or Afghanistan campaigns, but for illiberal politics they could also boast detention without trial, suspension of basic civil liberties, torture, extrajudicial killing, complicity with paramilitary organisations and a management of a climate of fear in justification of constitutional vandalism that this work tends to see as unique to the war on terror.

Politics Most Unusual is, therefore, a significant contribution to the substantial literature taking a broadly 'critical' perspective on the nature of post-9/11 politics. Its key strength is the engagement with a psychoanalytic approach to understanding the nature and significance of neglected aspects of religion and prejudice in contemporary political life and the ways in which 'spin', dissimulation and straightforward lying have ceased to be the mortal sins of politics that they once were. The authors deserve credit for this significant contribution to debate in this field.

John Williams

School of Government and International Affairs,

Durham University, UK 